\title{
Effects of Spirulina Platensis Algae on Growth Performance, Antioxidative Status and Blood Metabolites in Fattening Lambs
}

\author{
Mabrouk Ragab EL-Sabagh ${ }^{1}$, Mabrouk Attia Abd Eldaim ${ }^{2}$, D. H. Mahboub ${ }^{3}$ \& Mohamed Abdel-Daim ${ }^{4}$ \\ ${ }^{1}$ Department of Nutrition and Clinical Nutrition, Faculty of Veterinary Medicine, Kafrelsheikh University, Kafr \\ El-Sheikh 33516, Egypt \\ ${ }^{2}$ Department of Biochemistry and Chemistry of Nutrition, Faculty of Veterinary Medicine, Sadat City University, \\ Egypt \\ ${ }^{3}$ Department of Husbandry and Animal Wealth development, Faculty of Veterinary Medicine, Sadat City \\ University, Egypt \\ ${ }^{4}$ Pharmacology Department, Faculty of Veterinary Medicine, Suez Canal University, Ismailia, 41522, Egypt \\ Correspondence: Mabrouk Attia Abd Eldaim, Department of Biochemistry and Chemistry of Nutrition, Faculty of \\ Veterinary Medicine, Sadat City University, Egypt. E-mail: mabroukatia@yahoo.com
}

Received: September 29, 2013 Accepted: October 21, 2013 Online Published: February 15, 2014

doi:10.5539/jas.v6n3p92 URL: http://dx.doi.org/10.5539/jas.v6n3p92

\begin{abstract}
The objective of this study was to investigate the effects of Spirulina platensis powder (SPP) supplementation on growth performance, antioxidative status and blood metabolites in fattening lambs. Ten healthy lambs $(46.5 \pm 1.06$ $\mathrm{kg} \mathrm{BW})$ were randomly assigned to one of two treatments (5 lambs per treatment) and received either no supplementation or supplemented with SPP at a rate of $1 \mathrm{~g} / 10 \mathrm{~kg} \mathrm{BW} /$ day. The feeding experiment was conducted for 35 days with body weight recorded and blood samples collected on days 0,17 and 35 of the experiment. The paired Student's $t$-test for means was used for statistical analysis. The results showed that SPP supplementation improved final live body weight, daily live weight gain, feed intake and feed conversion ratio, compared to the control group $(\mathrm{P}<0.05)$. Also, haemoglobin, total white blood cell count, serum globulin, vitamin $\mathrm{A}$ and reduced glutathione were higher $(\mathrm{P}<0.05)$, while the aspartate amino transferase, alanine amino transferase, cholesterol, glucose and serum malondialdehyde levels were lower $(\mathrm{P}<0.05)$ in SPP supplemented group compared with the control. In conclusion, the findings of the present study clearly demonstrate that the SPP could be incorporated in fattening lambs diets as an antioxidant, immune-stimulant and growth promoter feed additive.
\end{abstract}

Keywords: fattening lambs, spirulina platensis, performance

\section{Introduction}

Intensive livestock production systems may be associated with multiple stressful incidents that negatively impact immune response and animal performance. The high metabolic rate during intensive feeding is accompanied by an increased production of free radicals, and any imbalance between production of these molecules and their safe disposal may culminate in oxidative stress, which can damage cells and tissues (Miller et al., 1993; Lykkesfeldt \& Svendsen, 2007). Therefore, under oxidative stress conditions, there is an increased demand for antioxidants to reduce the deleterious effects of free radicals on the immune system (Carroll \& Forsberg, 2007). Interestingly, feeding natural, rather than synthetic, antioxidant could be advantageous to animal welfare and consumer safety (Call et al., 2008; Makkar et al., 2007). The blue-green algae, Spirulina platensis, have been considered as a suitable natural antioxidant and immune-stimulant to humans and animals with fewer side effects and more cost effectiveness than synthetic products (Abdel-Daim et al., 2013; Belay, 2002; Khan et al., 2005). Recently, the impact of dietary Spirulina supplementation on animal health and productivity have been reported (Holman \& Malau-Aduli, 2012). However, studies on use of Spirulina platensis as a feed additive in ruminant feeding are still quite limited. To our knowledge, moreover, no studies have been undertaken on its usage with high concentrate diets. Therefore, the objective of this study was to test whether Spirulina platensis had beneficial effects when included in a high concentrate fed to fattening lambs. 


\section{Materials and Methods}

\subsection{Animals and Diets}

Ten healthy lambs ( $46.5 \pm 1.06 \mathrm{~kg} \mathrm{BW})$ were randomly allocated into two groups of 5 lambs each. Control lambs $(\mathrm{CON})$ received a diet without Spirulina, whereas in treated group, Spirulina platensis powder (SPP) was incorporated daily in the concentrate of each lamb at a rate of $1 \mathrm{~g} / 10 \mathrm{~kg}$ BW.day. The SPP was obtained from a commercial retailer in a powdered form (HERBAFORCE LTD, UNITED KINGDOM). The basal diet was formulated to meet the lamb's nutrient requirements in order to balance the body weight gain at a rate of $0.3 \mathrm{~kg} / \mathrm{day}$ (NRC, 1985). The composition of the basal diet is presented in Table 1. Diet was offered twice a day in the morning and evening with free access to water. The trial period was five weeks, with a pre-trial period of one week for adaptation to diets and facilities. Animals were weighed on days 0,17 and 35 of experiment, after fasting for twelve hours before the morning feedings.

Table 1. Ingredients and calculated chemical composition of experimental diet

\begin{tabular}{lr}
\hline Item & \multicolumn{1}{c}{$\%$} \\
\hline Ingredient & \\
Berseem hay & 14.65 \\
Wheat straw & 4.88 \\
Corn grains & 57.74 \\
Cotton seed meal & 13.07 \\
Soybean meal & 7.35 \\
Limestone & 0.79 \\
Salt & 0.49 \\
Sodium bicarbonate & 0.49 \\
Ammonium chloride & 0.24 \\
Vitamin-mineral premix & 0.29 \\
Calculated chemical composition & \\
DM & 88.73 \\
CP & 14.17 \\
TDN & 76.17 \\
NDF & 22.76 \\
ADF & 14.92 \\
EE & 4.14 \\
Ca & 0.73 \\
P & 0.37 \\
\hline
\end{tabular}

\subsection{Sampling and Analysis}

Feed and refusals were recorded daily. Body weight was recorded, and blood samples were collected from the jugular vein for each lamb on days 0,17 and 35 of the experiment. A portion of each blood sample was used for white blood cell (WBC) counts and to measure hemoglobin (Hb) (Linne \& Ringsrud, 1992) and reduced glutathione (GSH) (Beutler et al., 1963) concentrations using commercial kits (Biodiagnostic, Egypt). Remained blood samples were then centrifuged at $3000 \mathrm{x}$ g for $20 \mathrm{~min}$. The obtained sera were separated and stored at $-20^{\circ} \mathrm{C}$ until assayed spectrophotometrically (Spekol 11, Carl Zeiss Jena, Germany) for total protein (TP) and albumin concentrations as well as biochemical parameters, including serum enzymes activities as aspartate amino transferase (AST) and alanine amino transferase (ALT), blood urea nitrogen (BUN), triglyceride (TG) and cholesterol (CHO) levels (Young, 2001) according to the instructions of manufacturer (Endpoint kits from Diamond Diagnostics, Egypt). Globulin was calculated by subtracting albumin values from total serum protein. The albumin/globulin $(\mathrm{A} / \mathrm{G})$ ratio was also determined. Serum malondialdehyde (MDA) concentration was measured according to (Ohkawa et al., 1979) and the instructions of manufacturer (Biodiagnostic, Egypt). Retinol concentration in plasma was determined by modifying the method described by Suzuki and Katoh (1990). In brief, $50 \mathrm{ml}$ of ethanol and $150 \mathrm{ml}$ of hexane were added to $50 \mathrm{ml}$ of plasma, and the hexane phase was recovered after 
40-min mixing and 10-min centrifugation at $6500 \mathrm{x}$ g. Retinol concentrations were calculated based on the absorbance of hexane extracts at $325 \mathrm{~nm}$ and $453 \mathrm{~nm}$ using the equations described (Suzuki \& Katoh, 1990).

\section{Statistical Analysis}

All data are presented as mean \pm SEM. Mean comparisons were performed using Wilcoxon-Mann-Whitney test and considering $\mathrm{P}<0.05$ as level of significance.

\section{Results and Discussion}

\subsection{Growth Performance}

The growth performance of lambs is presented in Table 2. SPP supplementation to the diets of fatting lambs significantly increased $(\mathrm{P}<0.05)$ the final live body weights, daily live weight gain and feed intake compared with the control group. Moreover, the feed conversion ratio decreased $(\mathrm{P}<0.05)$ for SPP fed lambs compared with the control group. These results are consistent with previous reports that Spirulina supplementation induced greater live weights in cattle (Kulpys et al., 2009) and sheep (Holman et al., 2012). The better growth performance in lambs fed SPP supplemented diet may be a subsequence of high nutrient density of Spirulina as well as stimulation of the secretion of extracellular enzymes by the gut microflora (Tovar-Ramírez et al., 2002). Spirulina contains several nutrients, especially vitamins, minerals, essential fatty acids, amino acids and other nutrients that may promote faster growth (Gershwin \& Belay, 2008). Furthermore, Spirulina has previously been shown to decrease rumen protein degradation and produce changes in bacterial community composition with a subsequent increase the efficiency of rumen microbial crude protein production in steers (Panjaitan et al., 2010).

Table 2. Effect of Spirulina platensis powder on growth performance of fattening lambs

\begin{tabular}{lll} 
Item & \multicolumn{2}{c}{ Treatments } \\
\cline { 2 - 3 } & CON & SPP \\
\cline { 2 - 3 } Initial weight $(\mathrm{kg})$ & $46.0 \pm 0.50$ & $47.0 \pm 2.25$ \\
Final weight $(\mathrm{kg})$ & $50.4 \pm 0.92^{\mathrm{a}}$ & $55.3 \pm 2.10^{\mathrm{b}}$ \\
Daily weight gain $(\mathrm{kg} /$ day) & $0.127 \pm 0.012^{\mathrm{a}}$ & $0.236 \pm 0.015^{\mathrm{b}}$ \\
Daily feed intake (kg/day) & $1.64 \pm 0.002^{\mathrm{a}}$ & $1.72 \pm 0.010^{\mathrm{b}}$ \\
Feed conversion ratio & $13.2 \pm 1.38^{\mathrm{a}}$ & $7.35 \pm 0.41^{\mathrm{b}}$ \\
\hline
\end{tabular}

$\mathrm{CON}=$ Control. $\mathrm{SPP}=$ Spirulina platensis powder.

Mean values in the same row with different superscripts differ $(\mathrm{P}<0.05)$.

\subsection{Haematology}

$\mathrm{The} \mathrm{Hb}$ concentration and total $\mathrm{WBC}$ count of fattening lambs during the experiment are shown in Table 3 . The $\mathrm{Hb}$ concentration and total WBC count were higher $(\mathrm{P}<0.05)$ in SPP fed group compared to the control. Leucocytes play an important role in non-specific or innate immunity and their count can be considered as an indicator of relatively lower disease susceptibility (Matanović et al., 2007). The increased WBC production may be due to the presence of phycocyanin and polysaccharides components in Spirulina (Zhang, 1994). The WBC counts and Hb concentration were increased with supplementation of polysaccharide of Spirulina in mice (at a dose of 30-60 $\mathrm{mg} / \mathrm{kg}$ ) and dogs (at a dose of $12 \mathrm{mg} / \mathrm{kg}$ ) (Zhang et al., 2001). Similarly, Spirulina was found to enhance immunity in chickens fed $10 \mathrm{~g} / \mathrm{kg}$ of Spirulina platensis (Qureshi et al., 1996) and fish (Watanuki et al., 2006).

Table 3. Effect of Spirulina platensis powder on $\mathrm{Hb}$ concentration $(\mathrm{g} / \mathrm{dl})$ and total WBC counts (per $\mathrm{cmm})$ of fattening lambs

\begin{tabular}{|c|c|c|c|c|c|c|}
\hline \multirow{2}{*}{ Item } & \multicolumn{2}{|c|}{ 1st Sampling (0 day) } & \multicolumn{2}{|c|}{ 2nd Sampling (1 $7^{\text {th }}$ day) } & \multicolumn{2}{|c|}{ 3rd sampling ( $35^{\text {th }}$ day) } \\
\hline & $\mathrm{CON}$ & SPP & $\mathrm{CON}$ & SPP & $\mathrm{CON}$ & SPP \\
\hline $\mathrm{Hb}$ & $12.0 \pm 0.55$ & $13.5 \pm$ & $10.7 \pm 0.50^{\mathrm{a}}$ & $12.9 \pm 0.2$ & $12.2 \pm 0.20^{\mathrm{a}}$ & $13.0 \pm 0.09^{b}$ \\
\hline WBC & $11383 \pm 1490$ & $10883 \pm 1482$ & $8217 \pm 784$ & $9783 \pm 683$ & $7600 \pm 891^{\mathrm{a}}$ & $9900 \pm 908^{b}$ \\
\hline
\end{tabular}

$\mathrm{CON}=$ Control. $\mathrm{SPP}=$ Spirulina platensis powder.

$\mathrm{Hb}=$ Haemoglobin. $\mathrm{WBC}=$ White blood cells.

Mean values in the same row with different superscripts differ $(\mathrm{P}<0.05)$. 


\subsection{Biochemical Parameters}

Plasma TP, albumin, globulin, A/G ratio, AST, ALT, BUN, TG, CHO and glucose concentrations are presented in Table 4. Significant differences $(\mathrm{P}<0.05)$ in the serum globulin, AST, ALT, CHO, TG, BUN and glucose were found between the treatment groups (Table 4). There was no significant difference in the concentrations of TP, albumen and $\mathrm{A} / \mathrm{G}$ ratio between treatment groups. Supplementation with SPP induced significant elevation $(\mathrm{P}<0.05)$ in plasma globulin while significantly reduced $(\mathrm{P}<0.05)$ the AST, ALT, CHO and blood glucose concentrations. Furthermore, there was a significant increase in BUN with an unexpected increase in TG concentrations in lambs fed SPP supplemented diets.

Table 4. Effect of Spirulina platensis powder on biochemical parameters of fattening lambs

\begin{tabular}{|c|c|c|c|c|c|c|}
\hline \multirow{2}{*}{ Item } & \multicolumn{2}{|c|}{ 1st Sampling (0 day) } & \multicolumn{2}{|c|}{ 2nd Sampling ( $17^{\text {th }}$ day $)$} & \multicolumn{2}{|c|}{ 3rd sampling ( $35^{\text {th }}$ day) } \\
\hline & $\mathrm{CON}$ & SPP & $\mathrm{CON}$ & SPP & $\mathrm{CON}$ & SPP \\
\hline $\mathrm{TP}(\mathrm{g} / \mathrm{dl})$ & $4.34 \pm 0.21$ & $4.52 \pm 0.05$ & $4.71 \pm 0.09$ & $4.96 \pm 0.16$ & $5.37 \pm 0.11$ & $5.80 \pm 0.28$ \\
\hline Albumin (g/dl) & $2.08 \pm 0.05$ & $2.16 \pm 0.12$ & $2.50 \pm 0.15$ & $2.33 \pm 0.21$ & $2.99 \pm 0.17$ & $2.86 \pm 0.17$ \\
\hline Globulin (g/dl) & $2.36 \pm 0.10$ & $2.29 \pm 0.08$ & $2.26 \pm 0.06^{\mathrm{a}}$ & $2.62 \pm 0.09^{\mathrm{b}}$ & $2.37 \pm 0.09^{\mathrm{a}}$ & $2.93 \pm 0.21^{\mathrm{b}}$ \\
\hline $\mathrm{A} / \mathrm{G}$ ratio & $1.02 \pm 0.05$ & $0.91 \pm 0.08$ & $1.09 \pm 0.10$ & $0.89 \pm 0.11$ & $1.27 \pm 0.12$ & $0.98 \pm 0.09$ \\
\hline $\operatorname{AST}(\mathrm{U} / \mathrm{ml})$ & $51.2 \pm 2.00$ & $45.3 \pm 4.91$ & $50.0 \pm 2.55^{\mathrm{a}}$ & $40.5 \pm 1.50^{\mathrm{b}}$ & $85.7 \pm 14.5^{\mathrm{a}}$ & $39.3 \pm 1.86^{\mathrm{b}}$ \\
\hline $\operatorname{ALT}(\mathrm{U} / \mathrm{ml})$ & $21.3 \pm 0.67$ & $22.3 \pm 1.45$ & $30.7 \pm 2.73^{\mathrm{a}}$ & $20.3 \pm 0.95^{\mathrm{b}}$ & $65.3 \pm 12.8^{\mathrm{a}}$ & $25.7 \pm 4.84^{\mathrm{b}}$ \\
\hline Urea (mg/dl) & $19.3 \pm 0.39$ & $23.8 \pm 3.37$ & $25.3 \pm 3.75^{\mathrm{a}}$ & $40.0 \pm 1.42^{\mathrm{b}}$ & $19.4 \pm 2.05$ & $25.7 \pm 1.92$ \\
\hline Triglycerides (mg/dl) & $78.4 \pm 3.94$ & $76.5 \pm 2.42$ & $68.3 \pm 4.41^{\mathrm{a}}$ & $80.1 \pm 1.34^{\mathrm{b}}$ & $79.4 \pm 1.0$ & $73.6 \pm 5.54$ \\
\hline Cholesterol (mg/dl) & $45.9 \pm 2.46$ & $50.1 \pm 6.70$ & $62.8 \pm 1.73^{\mathrm{a}}$ & $49.6 \pm 2.48^{\mathrm{b}}$ & $81.2 \pm 10.4$ & $77.2 \pm 12.5$ \\
\hline Glucose (mg/dl) & $40.2 \pm 1.13$ & $35.4 \pm 5.78$ & $68.65 \pm 2.85^{\mathrm{a}}$ & $52.72 \pm 6.15^{b}$ & $54.9 \pm 10.6$ & $58.33 \pm 2.90$ \\
\hline
\end{tabular}

$\mathrm{CON}=$ Control. SPP $=$ Spirulina platensis powder.

$\mathrm{TP}=$ Total protein. $\mathrm{A} / \mathrm{G}$ ratio $=$ Albumin/globulin ratio. $\mathrm{AST}=$ Aspartate amino transferase. $\mathrm{ALT}=$ Alanine amino transferase.

Mean values in the same row with different superscripts $\operatorname{differ}(\mathrm{P}<0.05)$.

In this study, higher globulin concentration was found in the SPP supplemented group. The increased concentrations of plasma globulin may be related to the high protein contents in Spirulina (Gershwin \& Belay, 2008). Increased plasma globulin levels are thought to be associated with a stronger innate response in lambs and indicate higher resistance (Matanović et al., 2007). This result is supported by increased total leukocytic count in SPP fed group.

Supplementation with SPP reduced the total plasma CHO. This is in consistent with previous findings in rats (Kato et al., 1984) hamsters (Riss et al., 2007) rabbits (Cheong et al., 2010) and human (Ruitang \& Chow, 2010). Although the mechanism by which the SPP reduces CHO has not been fully examined, the hypocholesterolemic actions of SPP involve reducing plasma and liver CHO levels due to the increase in lipoprotein lipase and hepatic triglyceride lipase activity (Karkos et al., 2008), inhibition of both jejunal CHO absorption and ileal bile acid resorption (Nagaoka et al., 2005), in addition to modifying lipoproteins metabolism (decrease of low density lipoprotein and increase of high density lipoprotein; Torres-duran et al., 2007). Alternatively, the hypocholesterolemic activity of Spirulina is related to the large amount of cystine found in the C-phycocyanin protein of Spirulina (Nagaoka et al., 2005). A negative correlation was reported between the blood CHO concentrations and the level of cystine in dietary protein in rats fed a high CHO diet (Sugiyama et al., 1986).

Spirulina has been reported to have a hypolipidemic effect due to the C-phycocyanin protein which inhibits the pancreatic lipase activity in a dose-dependent manner (Torres-Duran et al., 2007). Controversy, the unexpected increase in the TG in SPP fed lambs in this study may imply that the Spirulina dose might be not enough to affect plasma TG or the supplementation period was not long enough for Spirulina to exert its lipid-modulating properties. Ishimi et al. (2006) reported that Spirulina may affect plasma lipids only in hyperlipidemic conditions. Further trails are required to characterize the efficacy of Spirulina in lowering blood lipid in ruminants. 
The activity of AST and ALT are indicators of hepatotoxicity (Azab et al., 2013). In the present study, treatment with Spirulina showed a significant decrease in AST and ALT indicating that Spirulina may play a protective role against liver dysfunctions (Bhattacharyya \& Mehta, 2012).

\subsection{Antioxidative Status}

Vitamin A, blood GSH and serum MDA concentrations are presented in Table 5. There was a significant increase $(\mathrm{P}<0.05)$ in vitamin A and GSH and a significant decrease $(\mathrm{P}<0.05)$ in MDA levels in SPP supplemented diets compared with control. Increased vitamin A and GSH and decreased MDA concentrations are indicators of improved oxidative defense of animal tissues (Celli, 2010). These results are in an agreement with previous reports stated that treatment with Spirulina could reduce oxidative stress with a consequent decrease in lipid peroxidation (Reddy et al., 2004; Riss et al., 2007). Reddy et al. (2004) suggested that Spirulina supplementation resulted in significantly higher activities of superoxide dismutase and catalase in the erythrocytes with a concomitant increase in reduced tripeptide glutathione content in broiler chickens. The antioxidative effect of Spirulina is related to several active ingredients, notably phycocyanin, polysaccharides, $\alpha$-tocopherol and $\beta$-carotene that have potent antioxidant activities working, individually or in synergy, directly on free radicals (Riss et al., 2007). Gershwin and Belay (2008) reported that the antioxidant activity of phycocyanin is about 20 times more efficient than vitamin C. In addition, Spirulina contains superoxide dismutase that acts indirectly by slowing down the rate of oxygen radical generating reactions (Belay, 2002).

In conclusion from the above results it can be concluded that SPP increased body weight gain, total WBC count, plasma globulin, vitamin A and reduced glutathione concentration while decreased liver enzymes activities, cholesterol, glucose and plasma malondialdehyde concentration. The potential application of Spirulina in fattening lambs diet as antioxidants to protect against free radicals cellular damage from stress, to enhance growth, and as an immunomodulator is worth exploring. Further experiments with implementation of different levels of Spirulina with higher replications and varying feeding practices are worthwhile to evaluate the nutritional value of Spirulina more accurately and precisely.

Table 5. Effect of Spirulina platensis powder on Vitamin A, GSH and MDA concentrations of fattening lambs

\begin{tabular}{lllllll}
\hline \multirow{2}{*}{ Item } & \multicolumn{3}{l}{ 1st Sampling $(0$ day $)$} & \multicolumn{2}{l}{ 2nd Sampling $\left(17^{\text {th }}\right.$ day $)$} & \multicolumn{2}{l}{ 3rd sampling $\left(35^{\text {th }}\right.$ day $)$} \\
\cline { 2 - 7 } & CON & SPP & CON & SPP & CON & SPP \\
\hline Vitamin A $(\mu \mathrm{g} / \mathrm{dL})$ & $60.9 \pm 2.5$ & $61.5 \pm 1.8$ & $69.0 \pm 5.1^{\mathrm{a}}$ & $106.3 \pm 3.8^{\mathrm{b}}$ & $69.1 \pm 0.35^{\mathrm{a}}$ & $71.4 \pm 0.84^{\mathrm{b}}$ \\
Blood GSH $(\mu \mathrm{M} / \mathrm{L})$ & $2.8 \pm 0.64$ & $3.0 \pm 0.74$ & $5.2 \pm 0.75^{\mathrm{a}}$ & $9.6 \pm 0.73^{\mathrm{b}}$ & $8.9 \pm 0.69^{\mathrm{b}}$ & $14.2 \pm 1.7^{\mathrm{b}}$ \\
Serum MDA $(\mathrm{nM} / \mathrm{ml})$ & $4.8 \pm 0.87$ & $4.1 \pm 0.93$ & $12.4 \pm 5.9$ & $8.0 \pm 2.6$ & $99.1 \pm 27.4^{\mathrm{a}}$ & $15.7 \pm 3.6$ \\
\hline
\end{tabular}

$\mathrm{CON}=$ Control. SPP $=$ Spirulina platensis powder.

$\mathrm{GSH}=$ Reduced glutathione. $\mathrm{MDA}=$ Reduced malondialdhyde.

Mean values in the same row with different superscripts differ $(\mathrm{P}<0.05)$.

\section{Acknowledgements}

This project was supported financially by the Science and Technology Development Fund (STDF), Egypt, Grant No. 736.

\section{References}

Abdel-Daim, M. M., Abuzead, S. M. M., \& Halawa, S. M. (2013) Protective Role of Spirulina platensis against Acute Deltamethrin-Induced Toxicity in Rats. PLoS ONE, 8(9), e72991. http://dx.doi.org/10.1371/journal.pone.0072991

Azab, S., Abdel-Daim, M., \& Eldahshan, O., (2013) Phytochemical, cytotoxic, hepatoprotective and antioxidant properties of Delonix regia leaves extract. Med Chem Res, 22, 4269-4277. http://dx.doi.org/10.1007/s00044-012-0420-4

Belay, A. (2002). The potential application of Spirulina (Arthrospira) as a nutritional and therapeutic supplement in health management, Review. J. Am. Nutraceut. Assoc., 5, 27-48.

Beutler, E., Duran, O., \& Kelly, M. B. (1963). Improved method for the determination of blood glutathione. J. Lab. Clin. Med., 61, 882-888. 
Bhattacharyya, S., \& Mehta, P. (2012). The hepatoprotective potential of Spirulina and vitamin C supplementation in cisplatin toxicity. Food Funct, 3, 164-169. http://dx.doi.org/10.1039/c1fo10172b

Call, D. R., Davis, M. A., \& Sawant, A. A. (2008). Antimicrobial resistance in beef and dairy cattle production. Anim. Health Res. Rev., 9, 159-167. http://dx.doi.org/10.1017/S1466252308001515

Carroll, J. A., \& Forsberg, N. E. (2007). Influence of stress and nutrition on cattle immunity. Vet. Clin. North Am. Food Anim. Pract., 23, 105-149. http://dx.doi.org/10.1016/j.cvfa.2007.01.003

Celli, P. (2010). The role of oxidative stress in small ruminants' health and production. Rev. Bras. Zootec., 39, 348-363. http://dx.doi.org/10.1590/S1516-35982010001300038

Cheong, S. H., Kim, M. Y., Sok, D. E., Hwang, S. Y., Kim, J. H., Kim, H. R., .. Kim, M. R. (2010). Spirulina prevents atheroschelerosis by reducing hypercholesterolemia in rabbits fed a high-cholesterol diet. J. Nutr. Sci. Vitaminol., 56, 34-40. http://dx.doi.org/10.3177/jnsv.56.34

Gershwin, M. E., \& Belay, A. (2008). Spirulina in human nutrition and health. CRC Press- Boca Raton, FL, USA.

Holman, B. W. B., Kashani, A., \& Malau-Aduli, A. E. O. (2012). Growth and body conformation responses of genetically divergent Australian sheep to Spirulina(Arthrospira platensis) supplementation. Am. J. Exp. Agr., 2, 160-173.

Holman, B. W., \& Malau-Aduli, A. E. O. (2012). Spirulina as a livestock supplement and animal feed. J Anim Physiol Anim Nutr., 97(4), 615-623. http://dx.doi.org/10.1111/j.1439-0396.2012.01328.x

Ishimi, Y., Sugiyama, F., Ezaki, J., Fujioka, M., \& Wu, J. (2006). Effects of Spirulina, a blue-green alga, on bone metabolism in overiectomized rats and hindlimb-unloaded mice. Biosci. Biotechnol. Biochem., 70, 363-368. http://dx.doi.org/10.1271/bbb. 70.363

Karkos, P. D., Leong, S. C., Karkos, C. D., Siraji, N., \& Assimkapoulos, D. A. (2008). Review of spirulina in clinical practice: Evidence-Based human applications. Evid. base Compl. Alternative Med., 14, 1-4.

Kato, T., Takemoto, K., Katayama, H., \& Kuwabara, Y. (1984). Effects of Spirulina (Spirulina platensis) on dietary hypercholesterolemia in rats. J. Jpn. Soc. Nutr. Food Sci., 37, 323-332. http://dx.doi.org/10.4327/jsnfs.37.323

Khan. Z., Bhadouria, P., \& Bisen, P. S. (2005). Nutritional and therapeutic potential of Spirulina. Curr. Pharm. Biotechnol., 6, 373-379. http://dx.doi.org/10.2174/138920105774370607

Kulpys, J., Paulauskas, E., Pilipavicius, V., \& Stankevicius, R. (2009). Influence of cyanobacteria Arthrospira (Spirulina) platensis biomass additive towards the body condition of lactation cows and biochemical milk indexes. Agron. Res., 7, 823-835.

Linne, J., \& Ringsrud, K. (1992). Basic techniques in clinical laboratory science (3rd ed.). Mosby Year Book. http://dx.doi.org/10.1016/j.tvj1.2006.06.005

Lykkesfeldt, J., \& Svendsen, O. (2007). Oxidants and antioxidants in disease: Oxidative stress in farm animals. Vet. $J ., 173,502-511$.

Makkar, H. P. S., Francis, G., \& Becker, K. (2007). Bioactivity of phytochemicals in some lesser-known plants and their effects and potential applications in livestock and aquaculture production systems. Animal, 1, 1371-1391. http://dx.doi.org/10.1017/S1751731107000298

Matanović, K., Severin, K., Martinkovic, F., Šimpraga, M., Janicki, Z., \& Barišic, J. (2007). Hematological and biochemical changes in organically farmed sheep naturally infected with Fasciola hepatica. J. Parasitol. Res., 101, 1657-1661.

Miller, J. K., Brzezinska-Slebodzinska, E., \& Madsen, F. C. (1993). Oxidative stress, antioxidants, and animal function. J. Dairy Sci., 76, 2812-2823. http://dx.doi.org/10.3168/jds.S0022-0302(93)77620-1

Nagaoka, S., Shimizu, K., \& Kaneko, H. (2005). A novel protein C-phycocyanin plays a crucial role in the hypocholesterolemic action of Spirulina platensis concentrate in rats. J. Nutr., 135, 2425-2430.

National Research Council. (1985). Nutrient requirement of sheep (6th ed.). Washington, DC: National Academy Press.

Ohkawa, H., Ohishi, W., \& Yagi, K. (1979). Assay for lipid peroxides in animal tissues by thiobarbituric acid reaction. Anal. Biochem, 95, 351-358. http://dx.doi.org/10.1016/0003-2697(79)90738-3 
Panjaitan, T., Quigley, S. P., McLennan, S. R., \& Poppi, D. P. (2010). Effect of the concentration of Spirulina (Spirulina platensis) algae in the drinking water on water intake by cattle and the proportion of algae bypassing the rumen. Anim. Prod. Sci., 50, 405-409. http://dx.doi.org/10.1071/AN09194

Qureshi, M. A., Garlich, J. D., \& Kidd, M. T. (1996). Dietary Spirulina platensis enhances humoral and cell-mediated immune functions in chickens. Immunopharmacol. Immunotoxicol, 18, 465-476. http://dx.doi.org/10.3109/08923979609052748

Reddy, B. S., Yuvaraj, N. Babitha, V. Ramnath, V., Philomina, P. T., \& Sabu, M. C. (2004). Antioxidant and hypolipidemic effects of Spirulina and natural carotenoids in broiler chicken. Indian Vet. J., 81, 383-386.

Riss, J., ecord'e, K. D., \& Sutra, T. (2007). Phycobiliprotein C-phycocyanin from Spirulina platensis is powerfully responsible for reducing oxidative stress and NADPH oxidase expression induced by an atherogenic diet in hamsters. J. Agric. Food Chem., 55, 7962-7967. http://dx.doi.org/10.1021/jf070529g

Ruitang, D., \& Chow, T. J. (2010). Hypolipidemic, antioxidant, and antiinflammatory activities of microalgae Spirulina. Cardiovasc. Therapeutics, 28, 33-45. http://dx.doi.org/10.1111/j.1755-5922.2010.00200.x

Sugiyama, K., Ohkawa, S., \& Muramatsu, K. (1986). Relationship between amino acid composition of diet and plasma cholesterol level in growing rats fed a high cholesterol diet. J. Nutr. Sci. Vitaminol., 32, 413-423. http://dx.doi.org/10.3177/jnsv.32.413

Suzuki, J., \& Katoh, N. (1990). A simple and cheap method for measuring serum vitamin A in cattle using only a spectrophotometer. Jpn. J. Vet. Sci., 52, 1281-1283. http://dx.doi.org/10.1292/jvms1939.52.1281

Torres-Durán, P. V., Ferreira-Hermosillo, A., \& Juárez-Oropeza, M. A. (2007). Antihyperlipemic and antihypertensive effects of Spirulina maxima in an open sample of Mexican population: a preliminary report. Lipids Health Dis., 6, 33. http://dx.doi.org/10.1186/1476-511X-6-33

Tovar-Ramírez, D., Zambonino, J., Cahu, C., Gatesoupe, F. J., Vázquez-Juárez, R., \& Lésel, R. (2002). Effect of live yeast incorporation in compound diet on digestive enzyme activity in sea bass (Dicentrarchus labrax) larvae. Aquaculture, 204, 113-123. http://dx.doi.org/10.1016/S0044-8486(01)00650-0

Watanuki, H., Ota, K., Malina, A. S., Kato, T., \& Sakai, M. (2006). Immunostimulant effects of dietary Spirulina platensis on carp, Cyprinus carpio. Aquaculture, 258, 157-163. http://dx.doi.org/10.1016/j.aquaculture.2006.05.003

Young, D. S. (2001). Effects of disease on clinical laboratory tests (4th ed.). Am. Assoc. Clin. Chem., 1504, 82-106.

Zhang, C. (1994). The effects of polysaccharide and phycocyanin from Spirulina platensis variety on peripheral blood and hematopoietic system of bone marrow in mice. Second Asia Pacific conference on Alga Biotechnology.

Zhang, H. Q., Lin, A. P., \& Sun, Y. (2001). Chemo and radio protective effects of polysaccharide of spirulina platensis on haematopoietic stem cells in dog and mice. Acta. Pharmacologica. Sinica, 22, 1121-1124.

\section{Copyrights}

Copyright for this article is retained by the author(s), with first publication rights granted to the journal.

This is an open-access article distributed under the terms and conditions of the Creative Commons Attribution license (http://creativecommons.org/licenses/by/3.0/). 